\title{
CEM ANOS DE SOLIDÃO COMPLETA 50 ANOS DE PUBLICAÇÃO
}

"Poetas e mendigos, músicos e profetas, guerreiros e malandros, todos nós, criaturas daquela realidade desaforada, tivemos que pedir muito pouco à imaginação, porque para nós o maior desafio foi a insuficiência dos recursos convencionais para tornar nossa vida acreditável. Este é, amigos, o nó da nossa solidão”. Foi assim que Gabriel García Márquez explicou o que considerava ser a solidão da América Latina durante seu discurso ao receber o Nobel de Literatura em 1982. Essa mesma solidão serviu de inspiração para aquela que é considerada a sua maior obra - e uma das maiores obras escritas na língua espanhola - Cem anos de solidão, que este ano completa meio século de publicação. Publicado pela primeira vez em 1967, a obra-prima do escritor colombiano já vendeu mais de 50 milhôes de cópias no mundo todo e foi traduzida para 35 idiomas, tendo sido lida por mais de 30 milhões de pessoas. O livro alçou o autor ao posto de um dos escritores mais importantes do século XX. García Márquez recebeu o Prêmio Internacional Neutstadt de Literatura, em 1972, e o Nobel de Literatura, em 1982 pelo conjunto de sua obra. Ao lado de Dom Quixote, de Miguel de Cervantes, Cem anos de solidão é considerado um dos livros mais importantes da literatura em língua espanhola.
Para comemorar os 50 anos da primeira publicação do livro está programada uma série de eventos, que começaram em janeiro e devem durar até o final do ano. Um dos primeiros foi uma leitura coletiva do livro em Cartagena, na Colômbia, que contou com a participação de 20 personalidades, 20 autoridades e 20 cidadãos escolhidos após uma convocatória pública. Durante quatro dias 60 pessoas leram, em ciclos de duas horas, trechos do romance. A Fundación Gabriel García Márquez para el Nuevo Periodismo Iberoamericano (FNPI), organizadora desse evento, sinalizou que promoverá durante o ano uma série de atividades para celebrar a data, mas os próximos eventos ainda não foram divulgados pela fundação.

50 ANOS DE SUCESSO Cem anos de solidão é considerada uma das obras mais importantes da literatura latino-americana. "Foi um estrondo desde a primeira edição, em 1967", explica Laura Hosiasson, professora do Departamento de Letras Modernas da Faculdade de Filosofia, Letras e Ciências Humanas (FFLCH) da Universidade de São Paulo (USP). "A partir daí, García Márquezse tornaria o primeiro escritor latino-americano que pôde se dar ao luxo de viver onde quisesse e como quisesse, impondo suas condiçôes aos editores".

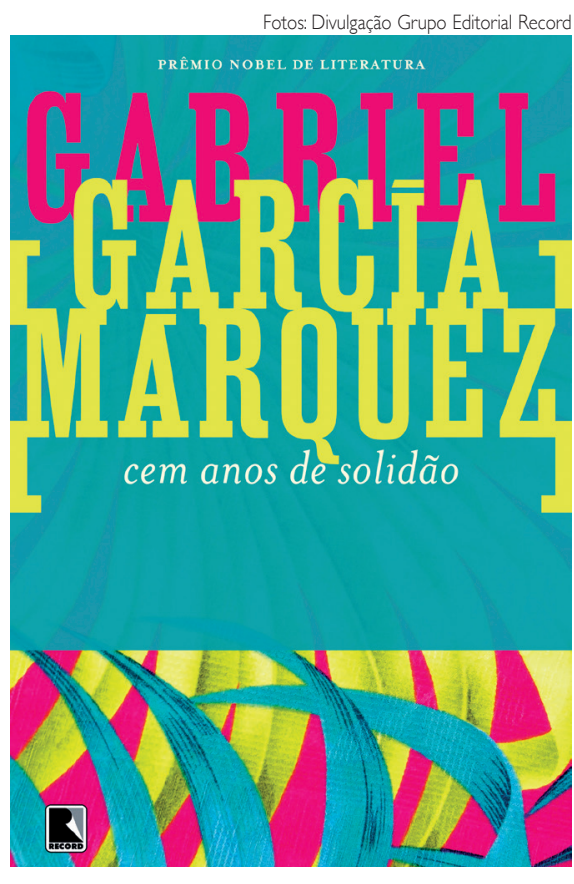

Mas até que isso acontecesse, o escritor teve que percorrer um longo e árduo caminho. Gabriel García Márquez trabalhou em vários jornais, foi correspondente internacional na Europa e nos Estados Unidos. Por sua amizade com Fidel Castro e suas críticas aos exilados cubanos, foi perseguido pela CIA. Também foi acusado de colaborar com a guerrilha na Colômbia e acabou tendo que se exilar no México. Passou por várias crises financeiras, mas sempre contou com o apoio dos amigos e nunca deixou de escrever.

Escrever Cem anos de solidão também não foi tarefa fácil. Para compor sua obra-prima, o autor levou 18 meses, durante os quais escrevia diariamente das $9 \mathrm{~h}$ às $15 \mathrm{~h}$. O próprio autor disse que teve um cataclismo da alma para compor o livro. A primeira versão das provas de impressão, que deveria ser entregue à editora com as devidas alteraçôes, teve mais de mil correções de pró- 
prio punho do autor, em um minucioso trabalho de lapidação.

Cem anos de solidão não foi a primeira obra de Gabriel García Márquez - antes dela, o autor havia publicado A revoada: o enterro do diabo (1955), Ninguém escreve ao coronel (1961) e Má hora: o veneno da madrugada (1962) - e nem era seu livro preferido. Inspirado na história de seus pais, $O$ amor em tempos de cólera (1985) era sua obra favorita.

\section{A REALIDADE FANTÁSTICA DA AMÉRICA} LATINA Cem anos de solidão não é apenas uma obra central para a América Latina por seu inegável valor literário, mas também porque reflete a realidade do continente, sua cultura e seus valores. Segundo o escritor peruano Mario Vargas Llosa, Cem anos de solidão está "profundamente ancorado na realidade da América Latina, dela se nutre e, transfigurando-a, acaba refletindo-a de maneira certeira e implacável". "Foi esse romance que definiu parte importante do que consideramos o que é ser latino-americano: essa mistura entre história e ficção, os fatos absurdos (políticos, econômicos, familiares) que entendemos como naturais, nossa formação marcada por militarismo, desigualdade e exploração", explica Karina de Castilhos Lucena, professora do Programa de Pós-Graduação do Instituto de Letras da Universidade Federal do Rio Grande do Sul (UFRGS).

García Márquez apresenta um povo que, mesmo miserável e desigual, carrega uma cultura rica de sentimentos, mitos e histórias maravilhosas. Um povo com o universo mágico tão entranhado em sua cultura que já não consegue diferenciar o real do irreal.
"Uma marca importante de García Márquez é se apropriar da história latino-americana e narrá-la de maneira quase absurda (aquilo que ficou conhecido como realismo mágico). Com isso, ele mistura o discurso historiográfico com o ficcional e mostra que muito do que consideramos 'verdade' tem uma boa dose de subjetividade, de narração", aponta Lucena. Então, o mágico e o maravilhoso não são utilizados pelo autor como uma forma de escape ou fuga, mas sim de fidelidade à realidade latino-americana. E, através de um minucioso trabalho estético com a linguagem, o autor leva o leitor pela história dos dramas de uma família, que vai se desenvolvendo paralelamente à história latino-americana. "Cada pequeno drama desenvolvido entre os seres que giram em torno à saga da família Buendía é alegoria da evolução de uma história maior, a história da América Latina”, explica Hosiasson. "Uma das formas interessantes desse movimento da alegoria está na relação entre crendice, superstição e poder. A força dos poderosos está cimentada sobre formas de manipulação da credulidade dos oprimidos". E é o próprio autor quem ensina o caminho para sair da opressão: "Eainda assim, diante da opressão, do saqueio e do abandono, nossa resposta é a vida. Nem os dilúvios, nem as pestes, nem a fome, nem os cataclismos, nem mesmo as guerras eternas através dos séculos e séculos conseguiram reduzir a vantagem tenaz da vida sobre a morte”, explica García Márquez em seu discurso no recebimento do Nobel de Literatura.

Chris Bueno

\section{FILOSOFIA}

REALIDADE OU SIMULAÇÃO?

Em suas clássicas reflexões filosóficas, René Descartes fala sobre um gênio maligno que, para nos ludibriar, se dedica a simular a realidade em que vivemos em seus mínimos detalhes. O filósofo explora, através da metáfora, que aparece em suas Meditaçôes sobre a filosofia primeira, em 1641, a ideia de que não existem garantias de que aquilo que pensamos sobre a realidade seja, de fato, real. A reinterpretação contemporânea desse gênio maligno se expressa na ficção científica do fim da década de 1990, em filmes como $13^{\circ}$ andar (1999), na trilogia Matrix, e, já na primeira década do século XXI, em episódios da série britânica Black mirror. A possibilidade de que a realidade seja simulada por um programa de computador, como no cinema, começou a receber maior atenção quando o filósofo sueco Nick Bostrom, da Universidade de Oxford, publicou a série de três hipóteses conhecidas como argumento da simulação, em 2003. No ano passado o assunto foi tema do Isaac Asimov Memorial Debate, do qual participaram os físicos teóricos James Gates, Universidade de Maryland, Lisa Randall, Harvard, o cosmólogo Max Tegmark, a física Zohreh Davoudi, ambos do Massachusetts Institute of Technology (MIT), e o filósofo David Chalmers, da Universidade de Nova York. Anu- 